\title{
GEOLOGIA E GEOQUÍMICA DAS ROCHAS METAULTRAMÁFICAS DA ANTIFORME CAPANÉ, SUÍTE METAMÓRFICA PORONGOS, RS
}

\author{
JULIANA CHARÃO MARQUES ${ }^{1}$, ARI ROISENBERG ${ }^{1}$, HARDY JOST ${ }^{2}$, \\ JOSÉ CARLOS FRANTZ ${ }^{1} \&$ ROBERTO DOS SANTOS TEIXEIRA ${ }^{3}$
}

\begin{abstract}
GEOLOGY AND GEOCHEMISTRY OF THE METAULTRAMAFIC ROCKS FROM CAPANÉ ANTIFORM, SUÍTE METAMÓRFICA PORONGOS, RS The metaultramafic rocks from the Capané Antiform were mapped in detail and their field, petrographic and geochemical characteristics are described. They consist of serpentinites with and without relic texture, subordinated talc schists, chlorite schists, and antophyllite-bearing schists. These rocks are tectonically hosted by a supracrustal sequence consisting of felsic to mafic calkalcaline to tholeiitic metavolcanic and metassedimentary rocks. Major, trace and rare earth element geochemistry suggest that the metaultramafic rocks are a basal part of a disrupted ophiolite. This is consistent with the subduction environment suggested by the metavolcanic rocks and explains both the tectonic emplacement of the serpentinites and the associated rodingites and deeply metassomatized mafic rocks. The mylonitic deformation created two superimposed foliations $\left(S_{1}\right.$ and $\left.S_{2}\right)$ gently folded during the late deformation stages. The association of antophyllite+olivine in relics of $S_{1}$ point to a metamorphic peak in the medium amphibolite facies, under a pressure lower than $6 \mathrm{kbar}$, while the transformation of antophyllite to clorite in relics of $\mathrm{S}_{2}$ resulted from retrograde metamorphism.
\end{abstract}

Keywords: Metaultramafic rocks, ophiolite, geochemistry, mylonitic deformation, metamorphism

Resumo As rochas metaultramáficas da Antiforme Capané foram mapeadas em detalhe e são descritas quanto às suas características de campo, petrográficas e geoquímicas. São compostas por serpentinitos com e sem textura reliquiar e, em menor quantidade, talco xistos, antofilita xistos e clorititos. Estas rochas estão imbricadas tectonicamente em uma sequiência supracrustal composta por rochas metavulcânicas félsicas a máficas de afinidade cálcio-alcalina a toleiítica e por rochas metassedimentares. A química de elementos maiores, traços e ETR sugerem que as rochas metaultramáficas representam a parte basal de um ofiolito desmembrado. Isto é consistente com o ambiente de subducção das rochas metavulcânicas e explica tanto o posicionamento tectônico dos serpentinitos quanto à ocorrência de rodingitos e rochas metabásicas metassomatizadas. A deformação milonítica gerou duas foliações $\left(S_{1}\right.$ e $\left.S_{2}\right)$ paralelas de baixo ângulo de mergulho, o que resultou em uma foliação composta suavemente dobrada durante os estágios finais da deformação. A paragênese antofilita+olivina na $S_{1}$ indica pico metamórfico da fácies anfibolito médio sob pressão inferior a 6 kbar e a transformação de antofilita em clorita na $\mathrm{S}_{2}$ resultou de retrometamorfismo.

Palavras-chave: Rochas metaultramáficas, ofiolito, geoquímica, deformação milonítica, metamorfismo

INTRODUÇÃO Diversas ocorrências de rochas ultramáficas são conhecidas no Escudo Sul-rio-grandense. A maioria localizase na porção oeste do Escudo e inclui, dentre outras, a de Palma (Garcia 1980, Chemale Jr. 1982), Cambaizinho (Remus 1990), Passo do Ivo (Santos et al. 1990), Mata Grande, Pedras Pretas e Santa Catarina (Villwock \& Loss 1973, Rego 1980), Cerro Mantiqueiras (Jost \& Hartmann 1984), Ibaré (Naumann 1985), Bossoroca (Zarpelon 1986, Wildner 1990) e Passo Feio (Bitencourt 1983). Na região central do Escudo, estas rochas são mais escassas e foram incluídas na Suíte Metamórfica Porongos (Ribeiro et al. 1966, Jost $\&$ Hartmann 1979). A origem e evolução das principais ocorrências foram recentemente revisadas por Hartmann \& Remus (2000).

Embora rochas ultramáficas representem alvos de importância econômica devido aos depósitos minerais que podem hospedar, $\mathrm{e}$ de interesse acadêmico pela natureza das informações tectônicas que encerram, nenhum outro trabalho de detalhe foi realizado nas ocorrências da Suíte Metamórfica Porongos desde o final da década de 70. As rochas metaultramáficas situadas na Antiforme Capané e associadas com a porção norte da Suíte, foram primeira- mente descritas durante trabalho de graduação realizado por formandos do Curso de Geologia da UNISINOS em 1977. Estas rochas constituem a maior ocorrência desta natureza na Suíte Metamórfica Porongos e consistem de serpentinitos com alguns cromititos podiformes e rodingitos, estes detalhados por Jost \& Hartmann (1979).

A Antiforme Capané localiza-se no extremo sul do município de Cachoeira do Sul, Rio Grande do Sul (Fig. 1). Parte da Antiforme Capané foi mapeada naescala 1:25.000 a a área com metaultramáficas detalhada na escala 1:12.500. A área mapeada limita-se pelas coor-

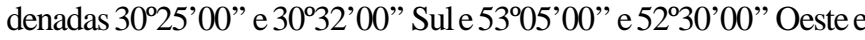
abrange o nariz e parte do flanco oeste da estrutura. Foram realizadas descrições petrográficas de 36 lâminas delgadas e 36 seções polidas, determinação de politipos de serpentina por Difratometria de Raios-X e análises químicas de elementos maiores e traços de 26 amostras e de elementos terras raras (ETR) de 3 amostras.

GEOLOGIA DA ANTIFORME CAPANÉ A Suíte Metamórfica Porongos (Jost \& Bitencourt 1980) é uma faixa de rochas

1 - Instituto de Geociências, Universidade Federal do Rio Grande do Sul, Av. Bento Gonçalves 9500, CEP 91501-970, Porto Alegre, RS, e-mail: juliana.marques@ufrgs.br; ari.roisemberg@ufrgs.br; jose.frantz@ufrgs.br

2 - Instituto de Geociências, Universidade de Brasília, CEP 70910-900, Brasília, DF, email: hjost@ opengate.com.br

3 - Curso de Pós-graduação em Geociências, Universidade Federal do Rio Grande do Sul, Av. Bento Gonçalves 9500, CEP 91501-970, Porto Alegre, RS 


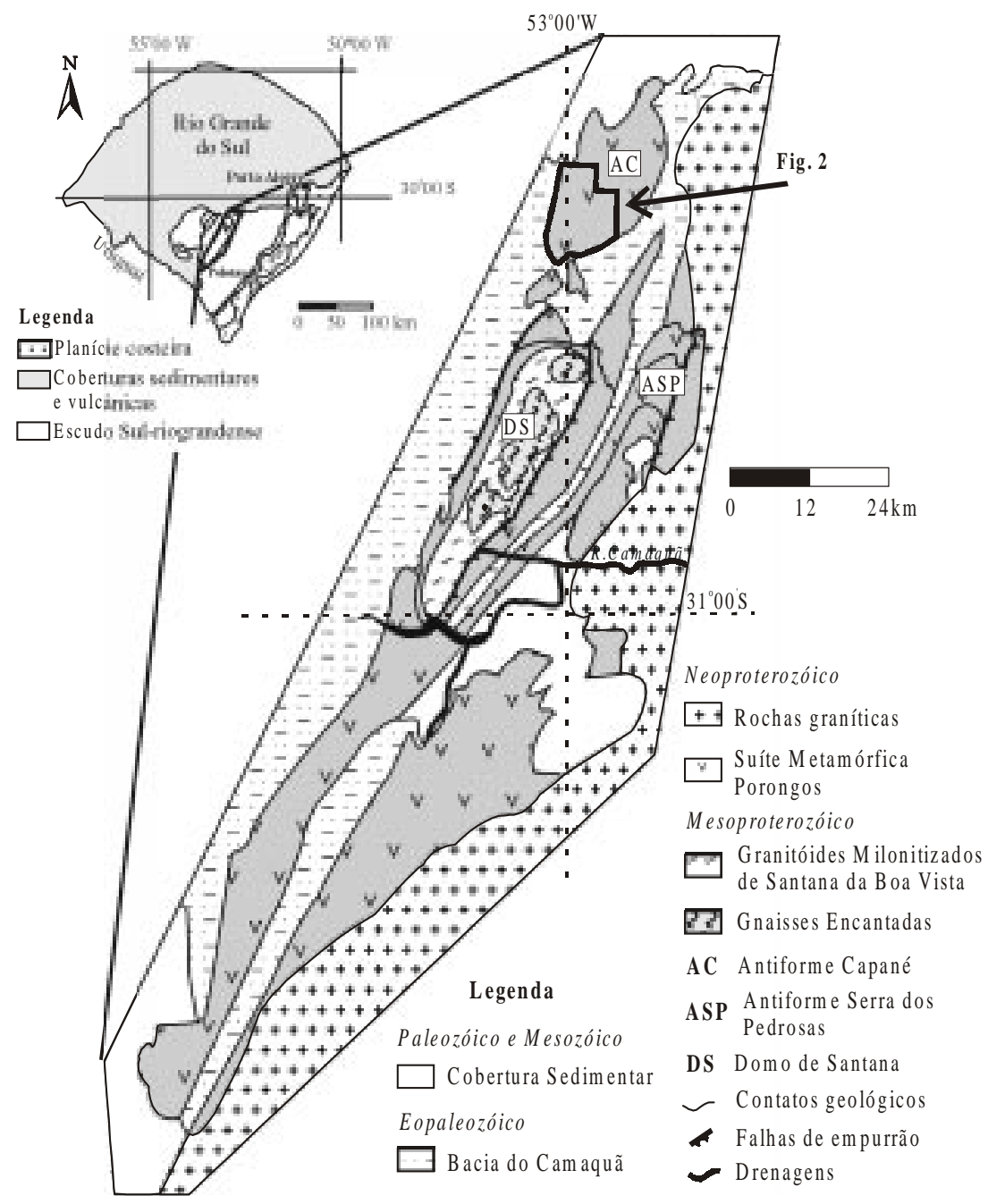

Figura 1 - Mapa geológico simplificado da parte central do escudo Sul-rio-grandense, mostrando a área de ocorrência da Suíte Metamórfica Porongos (extraído de Santos et al. 1989).

supracrustais de orientação NE com cerca de 150 km de comprimento situada na porção central do Escudo Sul-rio-grandense. A Suíte é melhor conhecida na porção a norte do Rio Camaquã onde está organizada em megaestruturas denominadas por Jost \& Bitencourt (1980) de Domo de Santana da Boa Vista, Antiforme Serra dos Pedrosas e Antiforme Capané (Fig. 1). Ao sul do Rio Camaquã, ocorre a Antiforme do Godinho, localizada na região do Passo da Cuia e formada por rochas semelhantes às descritas ao norte (Wildner et al. 1996).

Na região de Santana da Boa Vista, a Suíte Metamórfica Porongos está sobreposta discordantemente às unidades de embasamento, representadas pelos Gnaisses Encantadas e Granitóides Milonitizados de Santana da Boa Vista (Jost 1981, Porcher \& Fernandes 1990, Porcher 1992). No extremo sul, Remus et al. (1987) descrevem a existência de zonas de cavalgamento com imbricações de rochas do embasamento.

Dados geocronológicos da Suíte são escassos e a região ainda carece de estudo mais sistemático. Teixeira (1982) obteve uma idade $\mathrm{Rb} / \mathrm{Sr}$ convencional de $915 \mathrm{Ma}$ em milonito gnaisse da região de Santana da Boa Vista. Pelo mesmo método, Soliani Jr. (1986) datou rochas metavulcânicas intermediárias (Cerro Cambará) do
Complexo Cerro da Árvore, obtendo uma idade de $\pm 800 \mathrm{Ma}$, interpretando-a como a idade máxima do vulcanismo. Wildner et al. (1996) dataram metandesitos da Antiforme do Godinho pelo método U/Pb em zircão e obtiveram uma idade de $1.356 \pm 227 \mathrm{Ma}$, a qual, apesar do amplo intervalo, corresponderia à idade do vulcanismo contemporâneo com a sedimentação. Mais recentemente, em revisão sobre a evolução geológica do Escudo, Chemale Jr. (2000) relata uma idade de $783 \pm 6 \mathrm{Ma}$ (U-Pb em zircão, SHRIMP) de metariolito da Antiforme Capané e a interpreta como a idade de cristalização.

A Antiforme Capané localiza-se na porção setentrional da Suíte Metamórfica Porongos e consiste de variado conjunto de rochas submetidas a pronunciada deformação milonítica. O mapeamento geológico na escala 1:25000 de parte da estrutura permitiu subdividir as rochas supracrustais em uma seqüência metavulcânica e outra metassedimentar (Marques et al. 1998a,b). Estas seqüências estão orientadas segundo NE-SW e foram intrudidas por lentes de metagranitóide leucocrático orientadas segundo esta mesma direção. Lascas de gnaisse alcalino e rochas metaultramáficas ocorrem como imbricações na sequiência (Fig. 2A). Na área da antiforme, as rochas da Suíte apresentam intensa deformação registrada por 
duas foliações miloníticas $\left(\mathrm{S}_{1}\right.$ e $\left.\mathrm{S}_{2}\right)$ paralelas e originalmente de baixo ângulo de mergulho, resultando em foliação composta, posteriormente deformada em antiforme. O metamorfismo durante esta deformação foi retrogresssivo, da fácies anfibolito inferior $\left(S_{1}\right)$ para xisto verde $\left(\mathrm{S}_{2}\right)$ (Marques et al. 1998b).

A seqüência metavulcânica aflora ao longo do flanco oeste da Antiforme (Fig. 2A) e é composta por uma unidade félsica cálcioalcalina, e outra intermediária a máfica transicional a toleiítica. O vulcanismo foi, em parte, explosivo e sub-aquoso e é interpretado como produto de subducção de crosta oceânica sob um continente, possivelmente durante o Neoproterozóico (Marques et al. 1998a). A seqüência metassedimentar ocorre nas porções central e leste da estrutura e compreende metapelitos, quartzitos e quartzomilonitos, mais raramente metaconglomerados e mármores, e é interpretada como produto de sedimentação em mar raso, o que é compatível com o caráter sub-aquoso das rochas vulcânicas associadas (Marques et al. 1998b).

O metagranitóide que intrude as supracrustais ocorre na porção central da área, é sin-tectônico e de afinidade cálcio-alcalina (Marques et al. 1998a). Os gnaisses alcalinos ocorrem como várias intercalações tabulares nas supracrustais, são pré-cinemáticos e podem representar magmatismo associado a um evento extensional anterior ou concomitante à formação da bacia (Marques et al. 1998a). Esses gnaisses foram descritos por Hartmann \& Jost (1980) na região da antiforme e por Camozzato et al.(1994) na região de Candiota, extremo sul da faixa da Suíte.

PROCEDIMENTOS ANALÍTICOS Vinte e seis amostras de rochas metaultramáficas selecionadas para estudo geoquímico foram analisadas para elementos maiores no Laboratório de Geoquímica do Centro de Estudos em Petrologia e Geoquímica do Instituto de Geociências da Universidade Federal de Rio Grande do Sul. As amostras foram inicialmente lavadas em água corrente, secadas em estufa a menos de $100^{\circ} \mathrm{C}$ e pulverizadas em moinho com recipiente de Fe-W. Os óxidos $\mathrm{SiO}_{2}, \mathrm{TiO}_{2}, \mathrm{Al}_{2} \mathrm{O}_{3}, \mathrm{MnO}, \mathrm{MgO}$, $\mathrm{K}_{2} \mathrm{O}, \mathrm{CaO}, \mathrm{P}_{2} \mathrm{O}_{5}$ e FeO total $_{1}$, foram analisados por Fluorescência de Raios-X, em equipamento marca RIGAKU, modelo SIX-2000, empregando pastilhas de amostras pulverizadas e fundidas com Tetraborato de Lítio $(5 \mathrm{~g})$ e Iodeto de Lítio a $1 \%(0,25 \mathrm{ml})$. A reprodutibilidade dos dados analíticos foi controlada mediante réplica de uma amostra a cada grupo de dez amostras. Para efeitos de comparação, algumas análises de $\mathrm{FeO}_{\text {total }}$ foram refeitas por volumetria Redox. $\mathrm{O} \mathrm{Na} O \mathrm{O}$ foi analisado por Fotometria de Chama, o $\mathrm{FeO}$ pelo método de Wilson (1955) e o $\mathrm{Fe}_{2} \mathrm{O}_{3}$ recalculado por estequiometria.

Os elementos traço $\mathrm{Cr}, \mathrm{Ni}, \mathrm{Co}, \mathrm{V}, \mathrm{Cu}, \mathrm{Zn}, \mathrm{Ba}, \mathrm{Sr}, \mathrm{Zr}$ e Y foram

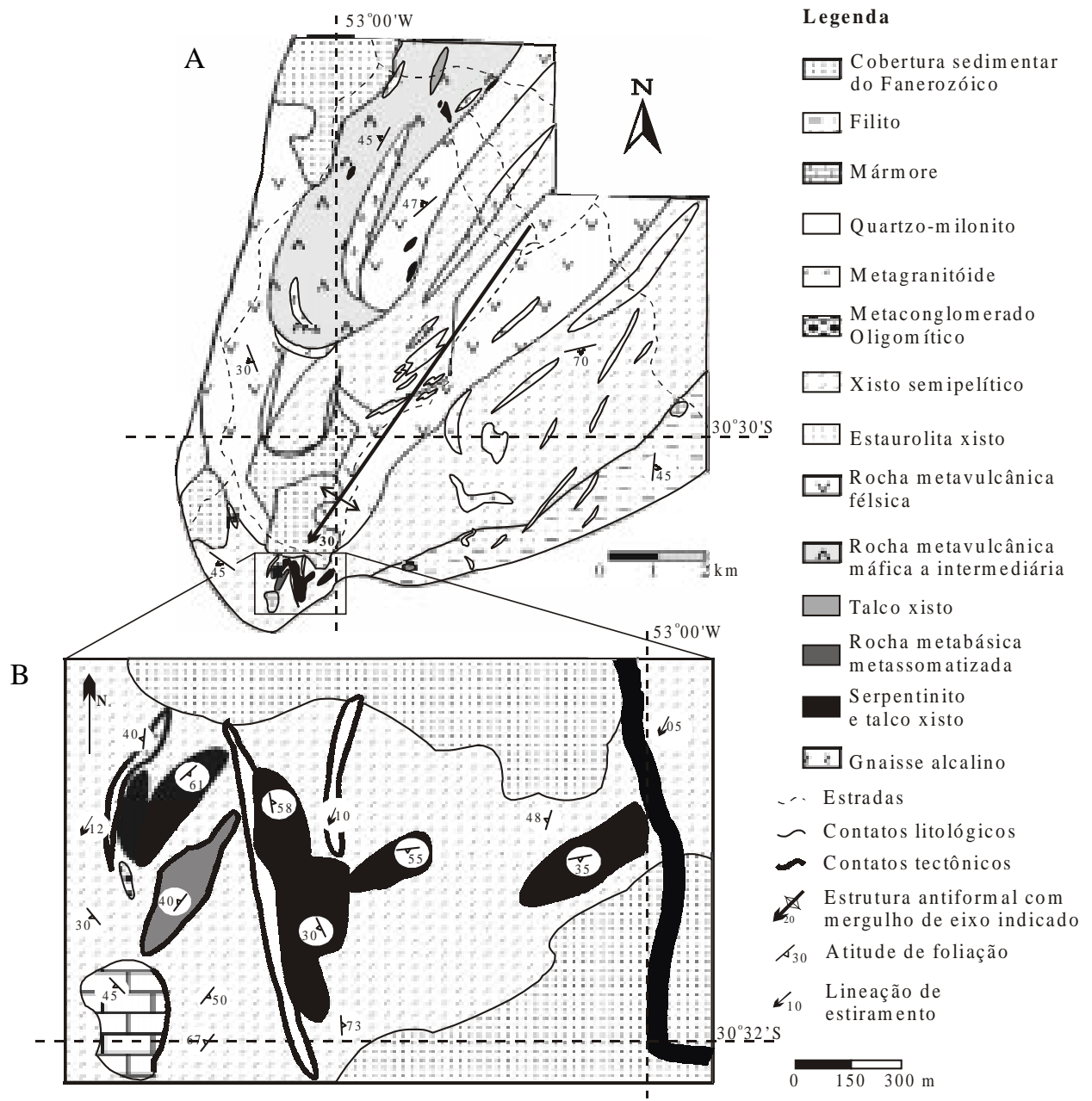

Figura 2 - (A) Mapa geológico simplificado da área estudada (Suíte Metamórfica Porongos, Antiforme Capané). (B) Mapa geológico simplificado da zona de maior ocorrência das lentes metaultramáficas. 
analisados no Laboratório de Geoquímica do Instituto de Geociências da Universidade de Brasília, empregando o método de Boaventura (1991), que consiste na decomposição ácida da amostra com $\mathrm{HF} / \mathrm{HClO}_{4} / \mathrm{HNO}_{3}$ e $\mathrm{HCl}$, e fusão dos resíduos com $\mathrm{LiBO}_{2}$. Os padrões analíticos foram preparados nas mesmas condições e no mesmo dia. As leituras de intensidade de emissão foram realizadas em espectrômetro SPECTRO FVMO3, com distância focal de $75 \mathrm{~cm}$, montagem Paschen-Runge. Análises de padrões foram efetuadas a cada cinco amostras. Três amostras foram analisadas para ETR ( $\mathrm{La}, \mathrm{Ce}, \mathrm{Nd}, \mathrm{Sm}, \mathrm{Eu}, \mathrm{Gd}, \mathrm{Dy}, \mathrm{Ho}, \mathrm{Er}, \mathrm{Yb}$, Lu) no Laboratório de Geoquímica da Geologia e Sondagens Ltda. - GEOSOL, Belo Horizonte.

Dez amostras de serpentinito foram selecionadas para a determinação de politipos de serpentina por Difratometria de Raios-X em equipamento RIGAKU, modelo D-MAX B, do Instituto de Geociências da Universidade de Brasília. As amostras foram preparadas segundo recomendações de Bish \& Reynolds Jr. (1989) e a varredura realizada de $2^{\circ}$ a $100^{\circ}$, com velocidade de $8 \%$ minuto, utilizando filtro de Mn e tubo de CuKa alimentado a $40 \mathrm{kV}$ e $20 \mathrm{~mA}$. Os dados foram tratados com emprego do programa RIGAKU RAD-B System.

\section{ROCHASMETAULTRAMÁFICASDAANTIFORMECAPANÉ}

As rochas metaultramáficas da Antiforme Capané compreendem lentes de serpentinito e xistos magnesianos orientados segundo NE-SW e restritos ao flanco ocidental da estrutura. Os principais corpos de serpentinito afloram no extremo sul da área, próximo a zona de charneira, junto à mina de calcário da CENTRALSUL. O corpo maior possui cerca de $1.200 \mathrm{~m}$ de comprimento e $400 \mathrm{~m}$ de largura. Os demais corpos são menores, estão em geral intemperizados e situam-se a norte da mina. Os contatos das lentes são tectônicos e marcados por ultramilonitos e filonitos das rochas encaixantes aos serpentinitos. Esta feição é bastante evidente nas lentes da parte sul da área, detalhada durante o mapeamento (Fig. 2B). Intercalações lenticulares de rochas metabásicas metassomatizadas ocorrem principalmente na porção sul da área, acompanham a orientação das rochas metaultramáficas e possuem espessura métrica e comprimento de dezenas de metros.

Os serpentinitos podem ser subdivididos em dois tipos, não mapeáveis na escala utilizada, com base na presença ou ausência de textura ígnea reliquiar. Os isentos de textura reliquiar são predominantes. Os portadores de textura reliquiar ocorrem como pods decimétricos em serpentinito foliado ou talco xisto e situam-se apenas na porção meridional da antiforme. Agregados de espinélio, em bolsões com até $20 \mathrm{~cm}$ de diâmetro (Fig. 3A), e venulações de rodingito são restritos às lentes metaultramáficas do extremo sul da área.

Os xistos magnesianos predominam no norte da área estudada, onde ocorrem em lentes decamétricas, comumente intemperizadas. Estas rochas compreendem talco xistos, antofilita xistos e clorititos. Talco xistos, quando menos deformados, exibem bandamento centimétrico dado pela alternância de bandas escuras e claras que ressaltam dobras tardias (Fig. 3B). No entanto, a forma mais comum de ocorrência de talco xistos é como lentes com textura milonítica muito fina, contendo prismas milimétricos de magnetita.

Serpentinitos com textura reliquiar (cumulados porfiríticos de olivina e ortopiroxênio) Os serpentinitos com textura reliquiar são finos, de aspecto vítreo, verde a cinza escuro e apresentam foliação incipiente. Apesar da serpentinização, cristais de espinélio primário estão em grande parte intactos e ocorrem homogeneamente disseminados. As amostras comumente apresentam fenoclastos entre 0,8 e $6,5 \mathrm{~mm}$ de diâmetro, verde claros, com contorno oval a retangular e que, em geral, ocorrem concentrados em bandas de 2,5 a 5,0 cm de espessura. Em algumas amostras, os fenoclastos estão orientados segundo o bandamento. A matriz é fina e a granulação varia de 0,1 a $0,6 \mathrm{~mm}$, localmente até $1 \mathrm{~mm}$. As bandas de fenoclastos se alternam com níveis de serpentinito escuro e maciço. O mineral predominante deste litotipo é representado por polimorfos de serpentina, com proporções menores de cromita, ferricromita, magnetita e sulfetos, e traços de ortopiroxênio. Carbonato, clorita e talco são secundários e ocorrem em amostras com deformação. As relações texturais entre fenoclastos e matriz sugerem que os protólitos destes serpentinitos consistem de cumulados.

A serpentina formou-se às custas tanto dos fenoclastos quanto dos constituintes primários da matriz. Difratogramas de Raios-X indicam que a serpentina é uma mescla de proporções variadas de Al-lizardita (1T) e crisotilo (2orc), com predomínio de lizardita.

A matriz consiste de pseudomorfos de serpentina sobre olivina. Os contatos intergranulares são marcados por filmes de magnetita, os quais evidenciam a textura poligonal original dos cumulados (Fig. 4A). A serpentina tem, em geral, uma textura hourglass que consiste de leques que convergem para o núcleo dos pretéritos cristais de olivina. A textura mesh também ocorre, mas se limita às bordas dos pseudomorfos e seus interstícios. Em amostras com textura mal preservada, a serpentina da matriz forma uma massa fina, por vezes grãos esferulíticos, em textura interlocking. Nestes casos, a textura original é reconhecida apenas por trilhas de magnetita \pm cromoespinélio.

Os fenoclastos pseudomorfizados por serpentina constituem, em algumas amostras, até cerca de $20 \%$ da rocha. São cristais prismáticos e apresentam textura de bastita com restos de clivagem (Fig. 4B). Apesar da dificuldade em determinar o mineral primário, a presença eventual de duas clivagens ortogonais sugere tratarse de ortopiroxênio. A serpentina desenvolveu-se segundo as clivagens e apresenta hábito ora fibroso ora em placas. Localmente a serpentina é substituída por talco. $\mathrm{O}$ ortopiroxênio reliquiar (Fig. 4C) é raro e está preservado em núcleos de pseudomorfos de serpentina (bastita). Suas características ópticas indicam que o mineral pertence à série enstatita-ortoferrosilita, no extremo rico em $\mathrm{MgO}$.

O cromoespinélio é primário e raramente está bem preservado devido à serpentinização e ao metamorfismo. Ocorre como núcleos submilimétricos envoltos por anéis de ferricromita e margens de magnetita, freqüentemente recortados por filetes destes minerais (Fig. 4D). O cromoespinélio ocorre como um mineral cumulus e intercumulus. Mesmo nos locais onde estão mais bem preservados, os cristais de cromoespinélio estão parcialmente transformados em ferricromita e magnetita ao longo das bordas ou fraturas. Quando fase cumulus, ocorre como grãos subédricos isolados, de até $5 \mathrm{~mm}$ de diâmetro, com feições de corrosão e não está acompanhado de fenoclastos de piroxênio, o que sugere que o cromoespinélio só é importante como fenoclastos em dunitos (Fig. 4E). Na presença de piroxênio, o cromoespinélio ocorre como cristais menores $(<5 \mathrm{~mm})$, isolados ou em trilhas intercúmulus que circundam fenoclastos, parcialmente substituídos por magnetita e ferricromita.

A ferricromita ocorre em proporções variadas, mas apenas como produto de alteração de cromoespinélio. O mineral contém freqüientes inclusões diminutas de silicatos, as quais lhe conferem um aspecto sujo. A magnetita é, em geral, produto de alteração 

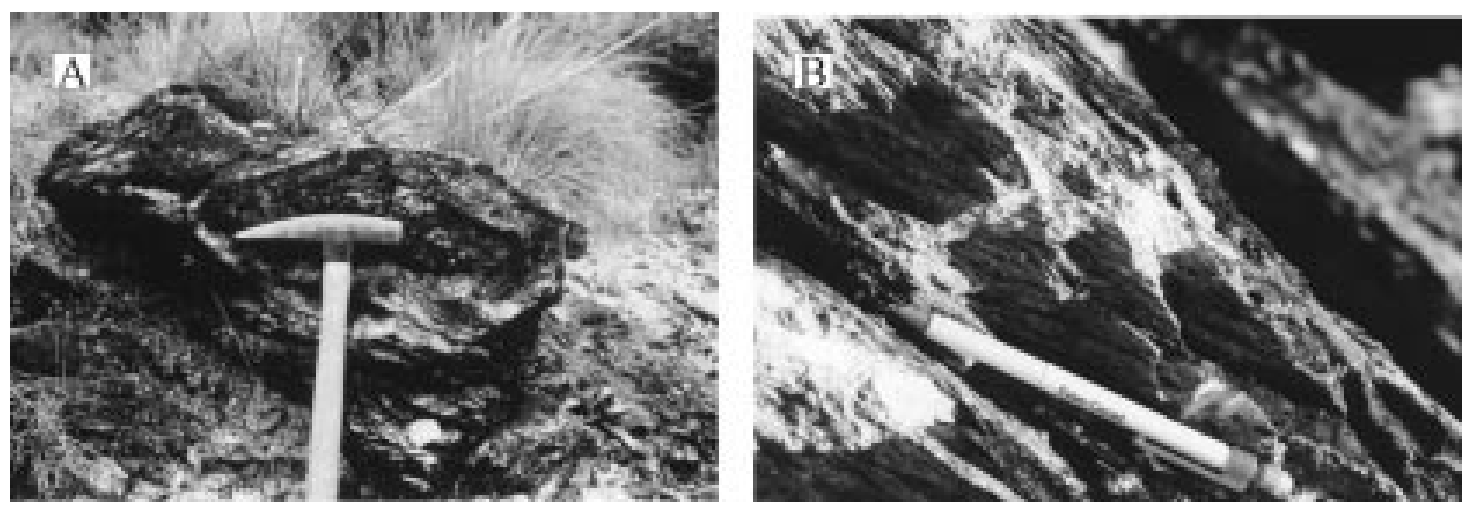

Figura 3 - (A) Bolsão (pod) de serpentinito com núcleo formado por agregados de espinélio. (B) Talco xisto com bandas de talco + carbonato intercaladas por bandas ricas em magnetita.

periférica ou ocorre ao longo de fraturas de cromoespinélio. $\mathrm{O}$ mineral também preenche clivagens e fraturas de piroxênio, como filonetes tardios de até 2,5 mm de largura. Quando substitui minerais intercumulus, a magnetita orienta-se perpendicularmente às faces dos cristais de olivina pseudomorfizada, destacando, assim, a textura original. Clorita tende a ocorrer nos locais onde há concentração de magnetita.

Os sulfetos são raros e compreendem calcopirita e pirita em cristais inferiores a $0,5 \mathrm{~mm}$, disseminados, isolados ou associados com magnetita da matriz ou com a que contorna cromoespinélio. $\mathrm{O}$ carbonato ocorre em proporções inferiores a $3 \%$ e pode estar ausente. O mineral ocorre como preenchimento de fraturas milimétricas descontínuas, com ou sem magnetita, como cristais disseminados, coroas em torno de fenoclastos ou, ainda, ao longo de clivagens de piroxênio, preferencialmente nos locais ricos em magnetita. A clorita é rara e, quando presente, ocorre em proporções inferiores a $1 \%$. Forma lamelas finas e resulta da transformação de cromoespinélio para ferricromita e magnetita. Sua baixa birrefringência, em tons de cinza, sugere tratar-se de Mg-clorita. O talco não excede $2 \%$ e ocorre em lamelas de até $2 \mathrm{~mm}$ desenvolvidas a partir de serpentina, em vênulas de até $1,5 \mathrm{~mm}$ de largura, ou, ainda, em exemplares mais deformados, como agregado lepidoblástico milimétrico.

Serpentinitos sem textura reliquiar Serpentinitos sem textura reliquiar são homogêneos, finos, verdes escuro a claro, foliados e/ ou fraturados. Venulações centimétricas de serpentina, talco e carbonato podem ser abundantes. Os seus constituintes principais compreendem serpentina e talco, subordinadamente carbonato, magnetita e ferricromita, geralmente acompanhados por traços de cromoespinélio, sulfeto e clorita. O cromoespinélio primário está transformado em ferricromita e magnetita, e ocorre em fraturas e venulações, indicando estágios de serpentinização avançada (Wicks \& Whittaker 1977).

A serpentina forma uma massa muito fina e consiste de Allizardita (1T) e crisotilo (2orc). Quando intercrescida com talco, mostra orientação incipiente. Gradações entre texturas tipo mesh $\mathrm{e}$ hourglass, preservadas em pods milimétricos, e de tipo interlocking em serpentina no entorno dos pods, sugere que, com aumento de deformação, a textura ígnea pseudomorfizada dá lugar a texturas metamórficas de baixo grau. Algumas amostras contêm apenas textura interlocking, traduzindo condições de serpentinização e metamorfismo mais pronunciadas, mas não necessariamente de deformação, em virtude da ausência de foliação. O talco, quando abundante, ocorre em lamelas isoladas de até $4 \mathrm{~mm}$ ou intercrescidas com serpentina orientadas segundo uma foliação. Quando brechados, os serpentinitos maciços são recortados por veios de talco. $\mathrm{O}$ carbonato ocorre freqüentemente segundo a foliação, mas também em massas disseminadas e em vênulas, o que evidencia um caráter tanto sin- quanto pós-cinemático. O mineral apresenta maclas, em geral de deslizamento, e é um freqüente associado da magnetita. Em amostras com maior abundância de carbonato, este pode substituir completamente fenoclastos de magnetita.

A magnetita é o espinélio dominante, mas pode ocorrer apenas em traços ou mesmo estar ausente. O mineral resulta, preferencialmente, da oxidação de ferricromita, mas também pode ocorrer como fase independente disseminada na massa de serpentina. Vênulas de carbonato e/ou serpentina contendo cristais de magnetita euédricos de 0,03 a 0,6 mm de diâmetro são freqüentes. A clorita é magnesiana e se associa à magnetita, sugerindo tratar-se de produto residual da transformação metamórfica de cromoespinélio. $\mathrm{O}$ sulfeto é calcopirita e, em menor proporção, pirita. Ambos ocorrem ora como inclusões em magnetita, ora isolados e disseminados, ou, ainda, em trilhas no contato de ferricromita e magnetita. A última feição sugere que nem sempre a magnetita resulta da oxidação de cromoespinélio, mas pode ter se formado por remobilização, possivelmente durante o metamorfismo.

As venulações são tardias e comuns nesses serpentinitos, e mostram relações tais como entrecortes, superposições e transformações minerais nas intersecções, indicativas de que estas estruturas se formaram em diversos estágios (Fig. 4F). Foram identificados veios asbestiformes e não asbestiformes compostos por serpentina, serpentina + talco ou serpentina + carbonato + magnetita. Os veios asbestiformes são milimétricos, as fibras são inteiras e normais às paredes o que demonstra ausência de cisalhamento (Wicks \& Whittaker 1977). Os veios não asbestiformes são mais comuns e apresentam: (i) textura colunar ou pseudofibrosa; ou (ii) textura paralela às paredes. Sob microscópio, a extinção das fibras é comumente ondulante, o que pode, ou não, resultar de cisalhamento (Wicks \& Whittaker 1977).

Agregados de espinélio Quando menos deformados, os agregados de espinélio geralmente preservam a textura cumulática, caracterizada por cristais ovais a discretamente poligonais de até 1,5 $\mathrm{mm}$ de diâmetro. Textura do tipo occluded silicate (Fig. 5A) e estrutura bandada e nodular (Fig. 5B) são menos freqüentes. Por 

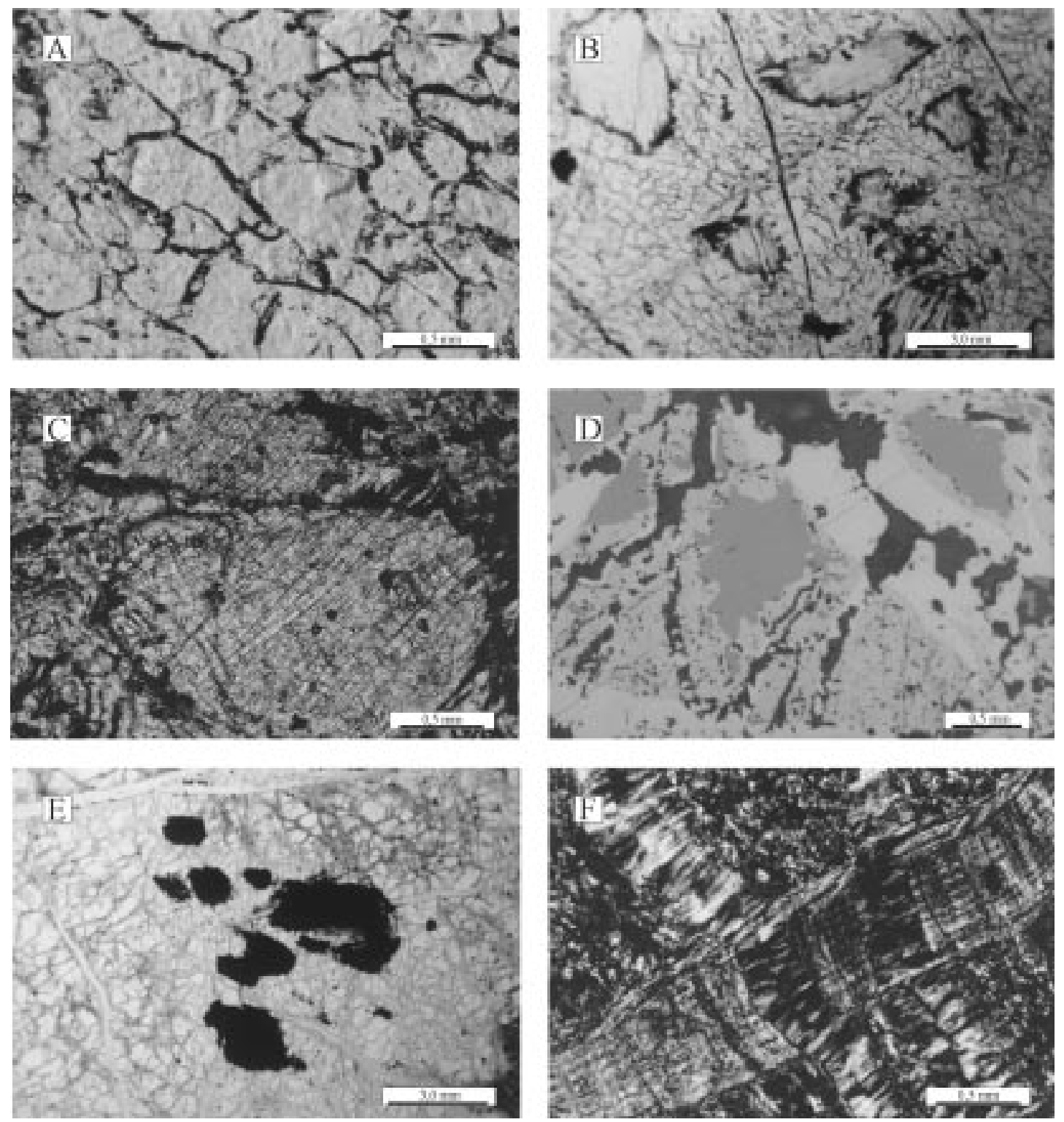

Figura 4 - Fotomicrografias ilustrando texturas dos serpentinitos da Antiforme Capané. (A) Textura poligonal de olivina pseudomorfizada por serpentina (Luz natural). (B) Fenocristais de piroxênio pseudomorfizado por serpentina (bastita) em matriz de olivina pseudomorfa (Luz natural). (C) Fenoclasto de ortopiroxênio parcialmente serpentinizado com espinélio junto às margens do cristal (Nicóis cruzados). (D) Espinélio zonado com núcleos de cromoespinélio envoltos em ferricromita e margens de magnetita (Luz refletida). (E) Fenocristais de espinélio em dunito serpentinizado (Luz natural). (F) Veios polifásicos de serpentina (Nicóis cruzados).

deformação, os agregados adquirem textura schlieren, com preservação apenas de magnetita em boudins. Os agregados estão normalmente contornados por serpentina muito fina, orientada e com estrutura de fluxo resultante de deformação. Os agregados são, em ordem crescente de abundância, compostos por ferricromita, cromoespinélio, magnetita e serpentina. Agregados submetidos à deformação mais intensa apresentam predomínio de magnetita em relação aos demais espinélios, aumento significativo de clorita e diminuição de cromoespinélio que ocorre apenas em traços. Carbonato, ilmenita e sulfeto podem ocorrer em traços.

A ferricromita em geral circunda o cromoespinélio, com preservação da textura original, e a sua proporção aumenta com a defor- mação. O mineral está comumente fraturado, o que o distingue do cromoespinélio, melhor preservado (Fig. 5C). A magnetita ora substitui cristais de cromoespinélio e ferricromita, ora preenche fissuras do serpentinito. A sua abundância aumenta com a intensidade de deformação rúptil, o que a define como tardia. A ilmenita é rara e ocorre como diminutas lamelas de exsolução em magnetita apenas em amostras mais deformadas e metassomatizadas. A pirita é ora intersticial ora inclusa em ferricromita e magnetita. $\mathrm{O}$ mineral só foi observado em amostras mais deformadas e em rochas metassomáticas, o que sugere um caráter secundário. $\mathrm{O}$ carbonato se formou a partir de corrosão de magnetita. A clorita é da variedade rica em ferro, como sugere sua cor de interferência azul 
berlim, e é produto de metamorfismo sobre espinélios.

Rodingitos e rochas metabásicas metassomatizadas Rodingitos associados às rochas metaultramáficas da Antiforme Capané foram descritos, pela primeira vez, por Jost \& Hartmann (1979), com detalhes sobre seu modo de ocorrência e características petrográficas e químicas. Estas rochas são raras na área, têm distribuição aleatória e ocorrem em massas disformes ou vênulas de até $10 \mathrm{~cm}$ de largura e $1,60 \mathrm{~m}$ de comprimento, geralmente envoltas por auréola milimétrica a centimétrica rica em clorita. Em geral ocorrem como fragmentos dispersos pela superfície do terreno, raramente in situ, e se distinguem de fragmentos de metaultramáfica pela cor e densidade elevada.

Os rodingitos são finos a muito finos, verde claros a pretos, densos e maciços a discretamente bandados. Seus constituintes minerais compreendem proporções variadas de hidrogranada, vesuvianita, diopsídio e clorita, com traços de zoizita, carbonato, serpentina e sulfeto. Rodingitos em massas disformes se associam preferencialmente a serpentinito com maior abundância de óxidos e diferem dos de veio pela ausência de diopsídio e maiores proporções de clorita e, dentre os óxidos, o predomínio de ilmenita e leucoxênio de alteração.

As rochas metabásicas metassomatizadas possuem textura lepidoblástica e granoblástica média a grossa, e consistem de proporções variadas de plagioclásio, clorita, biotita, quartzo, diopsídio, hidrogranada, vesuvianita, carbonato, calcopirita e traços de anfibólio, apatita, calcopirita, epidoto e mica branca. O plagioclásio tem entre 3,0 e 5,0 mm de diâmetro e está parcialmente transformado em carbonato. Maclas polissintéticas estão apenas parcialmente preservadas. A hidrogranada ocorre em agregados de até 6 $\mathrm{mm}$, compostos por grãos de 0,005 a $0,1 \mathrm{~mm}$. Os cristais individuais são euédricos a subédricos, isótropos a fracamente anisótropos e estão, em geral, oxidados, o que lhes confere um aspecto sujo. A vesuvianita ocorre como cristais com diâmetro médio de $0,6 \mathrm{~mm}$ em agregados granoblásticos de $1 \mathrm{~mm}$ de diâmetro médio. O mineral é geralmente límpido e fraturado e, em algumas amostras, pode predominar sobre os demais. O diopsídio tem entre 0,5 e 5,5 $\mathrm{mm}$ de diâmetro e, por vezes, possui lamelas curvas de ortopiroxênio segundo uma direção de geminação, cuja espécie é de difícil determinação devido a parcial alteração para clorita e serpentina. Filetes de vesuvianita e hidrogrossulária freqüentemente cortam os cristais de diopsídio, sugerindo que estas rochas se formaram durante sucessivos estágios, o mais tardio, talvez, em regime rúptil. A clorita é abundante, marca a foliação e ocorre nas variedades magnesiana e férrica. A zoizita é rara e ocorre em cristais inferiores a $0,1 \mathrm{~mm}$. Carbonato e serpentina ocorrem apenas como diminutos filetes nos rodingitos. O primeiro é mais abundante nas rochas metabásicas, nas quais substitui o plagioclásio e o piroxênio e preenche veios e espaços discordantes da foliação, o que sugere uma origem tardia. O carbonato também constitui bandas alternadas com bandas de clorita. A calcopirita ocorre disseminada e é mais abundante nos metabasitos metassomatizados.

Xistos magnesianos Os xistos magnesianos associados aos serpentinitos compreendem antofilita xistos, clorititos e talco xistos.

ANTOFILITAXISTOS Antofilita xistos consistem de porfiroblastos de antofilita imersos em matriz que perfaz, em média, $60 \%$ da rocha e é constituída por clorita, carbonato e olivina, subordinadamente serpentina, cromoespinélio, magnetita, calcopirita e pirita. Os porfiroblastos de antofilita são fibrorradiados, alcançam até $1 \mathrm{~cm}$
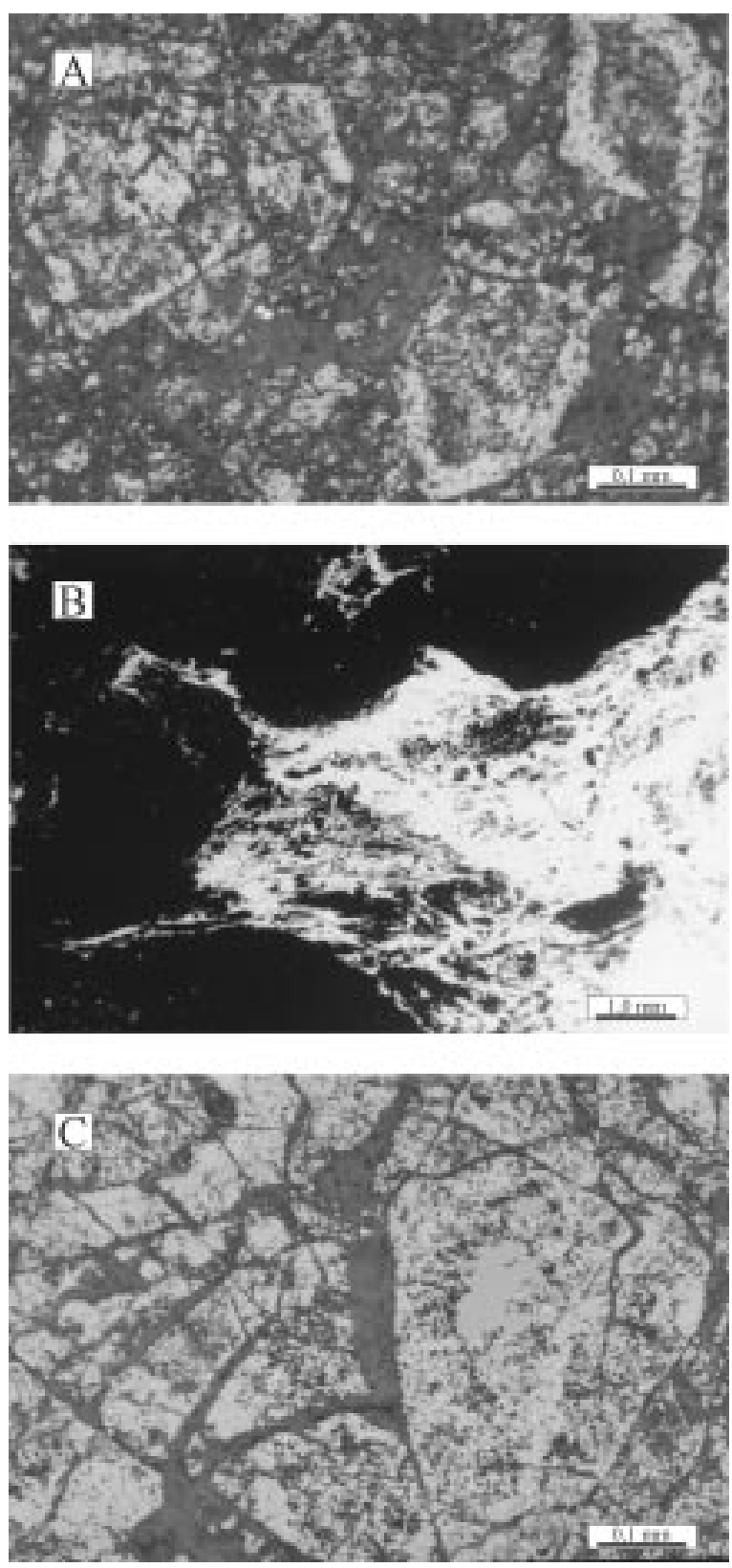

Figura 5 - Fotomicrografias que ilustra texturas dos agregados de espinélio de serpentinitos da Antiforme Capané. (A) Cristais poligonais de espinélio com núcleos ricos em silicatos (textura do tipo occluded silicate) (Luz refletida). (B) Textura nodular, comum em ocorrências podiformes e ofiolitos (Luz natural). (C) Núcleo de cromoespinélio circundado por ferricromita (Luz refletida).

de comprimento e são, em geral, mais abundantes em níveis ricos em carbonato. A olivina é esqueletal, tem até $0,5 \mathrm{~cm}$ de diâmetro, ocorre em bandas e está parcialmente transformada em agregados de magnetita, serpentina, clorita e, eventualmente, carbonato. Pseudomorfos de clorita sobre olivina são frequientes nas bandas ricas em antofilita. O carbonato, provável dolomita, é o constituinte principal da matriz, onde ocorre em massas disformes ou como cristais subédricos de até $4 \mathrm{~mm}$ com maclas de deslizamento. A 
clorita é secundária sobre cromoespinélio e olivina. A magnetita ocorre em filetes ou disseminada como diminutos cristais associados à calcopirita e pirita.

CLORITITOS Os clorititos têm textura lepidoblástica, localmente porfiroblástica e consistem de clorita $(>80 \%)$ e ilmenita + magnetita, com traços de antofilita, sulfetos e quartzo. A clorita é magnesiana, está orientada e tem tamanho médio de $0,15 \mathrm{~mm}$, mas pode alcançar até $1 \mathrm{~mm}$, quando apresenta estrutura micafish. A ilmenita, em cristais de até 4,0 mm, é o óxido predominante e está quase sempre associada à magnetita, onde pode ocorrer como exsolução irregular ou lamelar. A magnetita contem, em geral, bordas de martita. Os sulfetos são raros e ocorrem como inclusões submilimétricas em ilmenita e magnetita. A antofilita está geralmente oxidada e fraturada, possui de $0,3 \mathrm{~mm}$ a $1,5 \mathrm{~mm}$ de comprimento e está obliquamente orientada na foliação. O quartzo é subédrico, fraturado, disseminado e com dimensões entre 0,2 a $0,8 \mathrm{~mm}$.

TALCO XISTOS Os talco xistos apresentam textura decussada que, com incremento da deformação, passa para lepidoblástica crenulada. Seus constituintes compreendem talco, carbonato e magnetita. O talco é lamelar, com dimensões que, com incremento da deformação, variam de $0,3 \mathrm{~mm}$ a $0,5 \mathrm{~mm}$ em pods a inferiores a $0,2 \mathrm{~mm}$. O carbonato é, em rochas menos deformadas, límpido, euédrico a subédrico, com até $0,3 \mathrm{~mm}$ de diâmetro e sua abundância decresce em espécimens mais deformados. A magnetita é euédrica a subédrica, de até $1,0 \mathrm{~mm}$ e, nos exemplares menos deformados, ocorre em agregados granulares em torno de núcleos de ferricromita. Em rochas mais deformadas, a magnetita é fina $(<0,6 \mathrm{~mm})$, disseminada e orientada segundo a foliação, está martitizada e é acompanhada de óxidos amorfos.

GEOQUíMICA A Tabela 1 contém os dados analíticos das rochas metaultramáficas estudadas. As amostras incluem serpentinitos puros, serpentinitos ricos em óxidos com traços de paragêneses metassomáticas e serpentinitos metassomatizados. Os diagramas de variação com emprego de $\mathrm{MgO}$ como discriminante (Figs. 6 e 7) permitem distinguir as rochas metassomatizadas das demais. $\mathrm{O}$ metassomatismo provocou aumento das proporções de $\mathrm{Al}_{2} \mathrm{O}_{3}, \mathrm{CaO}, \mathrm{FeO}_{\text {total }}, \mathrm{TiO}_{2}, \mathrm{MnO}, \mathrm{P}_{2} \mathrm{O}_{5}, \mathrm{~V}$, $\mathrm{Cu}$ e $\mathrm{Y}$, e os elementos mais removidos incluem $\mathrm{MgO}$, Ni e Cr. O $\mathrm{Na}_{2} \mathrm{O}$ e o $\mathrm{Zr}$ apresentam forte dispersão e o teor de $\mathrm{SiO}_{2}$ é, naturalmente, menor nas amostras ricas em espinélios.

As proporções de $\mathrm{FeO}, \mathrm{TiO}_{2}, \mathrm{~V}$ e $\mathrm{MnO}$ nas rochas metassomatizadas reflete a abundância de magnetita, ilmenita e polimorfos de $\mathrm{TiO}_{2}$ e as de $\mathrm{Cu}$ se explicam pela presença de calcopirita secundária. A diminuição de $\mathrm{Mg}$ e aumento de $\mathrm{Al}$ resulta da variação nas proporções de clorita e talco nas rochas mais transformadas.

As rochas metaultramáficas estudadas são empobrecidas em ETR quando comparadas ao manto primitivo e apresentam um padrão côncavo (Fig. 8). Estas rochas são enriquecidas em ETRL em relação a ETRP, apresentam anomalia negativa de Eu e razão $\mathrm{La}_{\mathrm{N}} / \mathrm{Yb}_{\mathrm{N}}$ entre 5 e 12 .

As características geoquímicas dos serpentinitos, cujos protólitos consistiam de harzburgitos e dunitos ricos em cromoespinélio, são homogêneas, variáveis apenas quando ocorrem paragêneses metassomáticas.

As elevadas proporções de $\mathrm{MgO}$ (média de 45\%) e a abundância de $\mathrm{Ni}$ (2000ppm) e Cr (2000ppm) são compatíveis com peridotitos alpinos/ofiolíticos (Fig. 9A). O diagrama da figura 9B sugere uma afinidade com peridotitos metamórficos de manto e não com cumulados de intrusões acamadadas. Entretanto, o baixo conteúdo de $\mathrm{ETR}_{\text {total }}$ (média $<5 \mathrm{ppm}$ ), o seu padrão côncavo e o enriquecimento relativo em ETRL não são, em primeira instância, compatíveis com o esperado para peridotitos mantélicos. Por outro lado, estas características são similares as de harzburgitos e dunitos de seções basais de ofiolitos (Frey 1984, Melcher et al. 1999), nos quais o padrão dos ETR se explica por enriquecimento após a fusão parcial do manto. Segundo McDonough \& Frey (1989), isto pode ser explicado mediante três diferentes mecanismos, isto é, mistura de líquidos ricos em ETRL com resíduos empobrecidos, interação do líquido com peridotitos encaixantes ou formação de resíduos durante fusão seqüencial não equilibrada, na qual as fases líquidas em desequilíbrio com o resíduo herdariam o conteúdo de ETRP. O último modelo explicaria o padrão côncavo, mas não o aumento de ETRL em relação as ETRP (McDonough \& Frey 1989), mas Roden et al. (1984) sugerem que processos metassomáticos poderiam explicar o forte aumento de ETRL na geração de manto enriquecido.

DEFORMAÇÃO E METAMORFISMO As rochas metaultramáficas apresentam sistematicamente as mesmas feições estruturais que as rochas supracrustais encaixantes, ou seja, acamamento original $\left(\mathrm{S}_{\mathrm{o}}\right)$ transposto e paralelo a duas foliações $\left(\mathrm{S}_{1}\right.$ e $\left.\mathrm{S}_{2}\right)$. No entanto, comparativamente às encaixantes, os efeitos de cisalhamento nem sempre são óbvios nas rochas ultramáficas devido à baixa competência dos serpentinitos, o que permite intenso dobramento e transposição generalizada. Serpentinitos com textura reliquiar possuem um bandamento interpretado como $\mathrm{S}_{0}, \mathrm{o}$ qual é cortado por estreitas faixas de alta deformação $\left(S_{1}+S_{2}\right)$ marcadas por serpentinito milonitizado. Os xistos magnesianos, quando intensamente deformados, são tectonitos $\mathrm{S}$ nos quais os minerais filitosos marcam a foliação milonítica $\left(\mathrm{S}_{2}\right)$. Nestes, a paragênese antofilita + olivina representa restos de uma foliação $S_{1}$. A foliação composta está comumente dobrada, ora em isoclinais, ora em dobras apertadas ou abertas e representam fases distintas de deformação progressiva, a exemplo de xistos da seqüência supracrustal encaixante, descritos por Marques et al. (1998b).

Nas rochas metaultramáficas, o grau metamórfico mais elevado é dado pela associação antofilita + olivina que indica fácies anfibolito médio, sob pressão inferior a 6 kbar e temperatura entre $650^{\circ} \mathrm{Ce} 700{ }^{\circ} \mathrm{C}$ (Bucher \& Frey 1994). A transformação de antofilita em clorita resultou de retrometamorfismo.

O padrão de deformação e as condições de temperatura e pressão estimadas para o metamorfismo registrado nas rochas metaultramáficas são consistentes com o descrito por Marques et al. (1998b) nas rochas supracrustais. Estes autores estimam que o desenvolvimento da foliação $S_{1}$ ocorreu sob pressão mínima de $4,5 \mathrm{kbar}$ a temperatura mínima da ordem de $520^{\circ} \mathrm{C}$, portanto, na fácies anfibolito inferior de média pressão. Já durante a formação da $\mathrm{S}_{2}$, as condições não ultrapassaram a fácies xisto verde superior, sendo localmente mais baixas e, portanto, mais amenas do que as vigentes durante a formação de $S_{1}$, o que evidencia um generalizado retrometamorfismo. Os dados obtidos no presente trabalho permitem definir novos limites máximos de pressão e temperatura para o pico metamórfico durante a formação da foliação $S_{1}$, estimados, respectivamente, em $6 \mathrm{kbar}$ e entre $650^{\circ} \mathrm{Ca} 700^{\circ} \mathrm{C}$.

CONCLUSÕES O conjunto de rochas supracrustais que delineia a Antiforme Capané e na qual ocorrem as lentes de rochas metaultramáficas compreende uma seqüência metavulcânica e 
Tabela 1 - Resultados de análises químicas de óxidos de elementos maiores, elementos traços (ppm) e ETR (ppm) das rochas metaultramáficas da Antiforme Capané.

\begin{tabular}{|c|c|c|c|c|c|c|c|c|c|c|c|c|c|}
\hline & M-240 & M-240C & M-266C & M-266D & U-04A & U-05 & U-06 & U-07A & U-10A & U-12 & U-14 & U-15A & U-17 \\
\hline & Cloritito & Metas. & Serp. & Serp. & Serp. & Metas. & Metas. & Serp. & Serp. & Serp. & Esp. Serp. & Esp. Serp. & Serp. \\
\hline $\mathrm{SiO}_{2}$ & 28,3 & 46,78 & 45,3 & 44 & 45,7 & 44,98 & 43,3 & 44,98 & 44,75 & 43,68 & 29,15 & 20,57 & 45,48 \\
\hline $\mathrm{TiO}_{2}$ & 4,21 & 0,05 & 0,03 & 0,03 & 0,08 & 0,18 & 0,1 & 0,02 & 0,02 & 0,02 & 4,96 & 0,2 & 0,01 \\
\hline $\mathrm{Al}_{2} \mathrm{O}_{3}$ & 17,95 & 4,03 & 0,78 & 1,57 & 2,5 & 4,13 & 3,38 & 1,13 & 1,14 & 0,87 & 8,86 & 19,46 & 1,49 \\
\hline $\mathrm{Fe}_{2} \mathrm{O}_{3}$ & 7,56 & 3,56 & 6,31 & 6,77 & 3,58 & 4,54 & 5,93 & 6,12 & 6,01 & 7,19 & 18,08 & 23,13 & 4,85 \\
\hline $\mathrm{FeO}$ & 13,45 & 6,52 & 1,58 & 1,79 & 4,73 & 3,89 & 3,59 & 1,7 & 1,78 & 1,6 & 10,46 & 1,48 & 1,71 \\
\hline $\mathrm{MnO}$ & 0,14 & 0,15 & 0,06 & 0,08 & 0 & 0,13 & 0,11 & 0,09 & 0,1 & 0,12 & 0,3 & 1,1 & 0,16 \\
\hline $\mathrm{MgO}$ & 27,59 & 36,69 & 45,32 & 45,14 & 42,96 & 40,27 & 42,57 & 45,4 & 45,17 & 45,74 & 27,53 & 33,81 & 45,91 \\
\hline $\mathrm{CaO}$ & 0,13 & 1,91 & 0,36 & 0,21 & 0,01 & 1,44 & 0,74 & 0,3 & 0,56 & 0,57 & 0,14 & 0,23 & 0,02 \\
\hline $\mathrm{Na}_{2} \mathrm{O}$ & 0,46 & 0,47 & 0,24 & 0,38 & 0,43 & 0,39 & 0,25 & 0,22 & 0,43 & 0,18 & 0,43 & 0 & 0,35 \\
\hline $\mathrm{K}_{2} \mathrm{O}$ & 0,03 & 0,03 & 0,01 & 0,01 & 0,01 & 0,02 & 0,01 & 0,02 & 0,01 & 0,01 & 0,07 & 0 & 0,01 \\
\hline $\mathrm{P}_{2} \mathrm{O}_{5}$ & 0,17 & 0,1 & 0,01 & 0,01 & 0,01 & 0,01 & 0,01 & 0 & 0,01 & 0,01 & 0,02 & 0,02 & 0,01 \\
\hline $\mathrm{H}_{2} \mathrm{O}$ & 9,28 & 8,91 & 14,01 & 13,55 & 11,72 & 11,09 & 11,99 & 11,91 & 13,41 & 14,37 & 10,2 & 5,67 & 12,97 \\
\hline Total & 100 & 100 & 100 & 100 & 100 & 100 & 100 & 100 & 100 & 100 & 100 & 100 & 100 \\
\hline $\mathrm{Cr}$ & 10 & 1490 & 1310 & 2800 & 1920 & 2069 & 1565 & 2180 & 2069 & 1920 & 16 & 9900 & 2295 \\
\hline $\mathrm{Ni}$ & 205 & 1730 & 1690 & 1890 & 1890 & 1992 & 2040 & 2058 & 1995 & 1855 & 38 & 1157 & 2130 \\
\hline Co & 239 & 170 & 103 & 95 & 136 & 160 & 147 & 140 & 162 & 107 & 220 & 42 & 114 \\
\hline $\mathrm{V}$ & 1050 & 210 & 18 & 21 & 50 & 55 & 48 & 22 & 56 & 20 & 960 & 38 & 15 \\
\hline $\mathrm{Cu}$ & 2 & 10 & 7 & 2 & 12 & 4 & 8 & $<$ & 4 & 1 & 4 & 1 & $<$ \\
\hline $\mathrm{Zn}$ & 90 & 52 & 38 & 63 & 51 & 55 & 53 & 36 & 56 & 51 & 100 & 40 & 56 \\
\hline $\mathrm{K}$ & 249 & 249 & 83 & 83 & 83 & 166 & 83 & 166 & 83 & 83 & 581 & 0 & 83 \\
\hline $\mathrm{Ba}$ & 11 & 80 & 22 & 6 & 158 & 9 & 32 & 6 & 9 & 6 & 57 & 3 & 798 \\
\hline $\mathrm{Sr}$ & 110 & 169 & 29 & 6 & $<$ & 115 & $<$ & 122 & 114 & $<$ & 127 & 69 & 136 \\
\hline $\mathrm{Zr}$ & 40 & 24 & 49 & 72 & 100 & 37 & 77 & 30 & 57 & 75 & 57 & 15 & 7 \\
\hline $\mathrm{Ti}$ & 25239 & 300 & 180 & 180 & 480 & 1079 & 600 & 120 & 120 & 120 & 29735 & 1199 & 60 \\
\hline $\mathrm{Y}$ & 5 & 2 & $<$ & $<$ & 2 & 5 & 3 & $<$ & 5 & $<$ & 14 & $<$ & $<$ \\
\hline & & & & & & & & & & & & & \\
\hline $\mathrm{La}$ & n.a. & n.a. & n.a. & n.a. & n.a. & n.a. & n.a. & n.a. & 0,933 & 0,749 & n.a. & n.a. & n.a. \\
\hline $\mathrm{Ce}$ & n.a. & n.a. & n.a. & n.a. & n.a. & n.a. & n.a. & n.a. & 1,955 & 3,1 & n.a. & n.a. & n.a. \\
\hline $\operatorname{Pr}$ & n.a. & n.a. & n.a. & n.a. & n.a. & n.a. & n.a. & n.a. & 0 & 0 & n.a. & n.a. & n.a. \\
\hline $\mathrm{Nd}$ & n.a. & n.a. & n.a. & n.a. & n.a. & n.a. & n.a. & n.a. & 0,51 & 0,47 & n.a. & n.a. & n.a. \\
\hline $\mathrm{Sm}$ & n.a. & n.a. & n.a. & n.a. & n.a. & n.a. & n.a. & n.a. & 0,08 & 0,08 & n.a. & n.a. & n.a. \\
\hline $\mathrm{Eu}$ & n.a. & n.a. & n.a. & n.a. & n.a. & n.a. & n.a. & n.a. & 0,017 & 0,019 & n.a. & n.a. & n.a. \\
\hline $\mathrm{Gd}$ & n.a. & n.a. & n.a. & n.a. & n.a. & n.a. & n.a. & n.a. & 0,08 & 0,1 & n.a. & n.a. & n.a. \\
\hline $\mathrm{Tb}$ & n.a. & n.a. & n.a. & n.a. & n.a. & n.a. & n.a. & n.a. & 0 & 0 & n.a. & n.a. & n.a. \\
\hline Dy & n.a. & n.a. & n.a. & n.a. & n.a. & n.a. & n.a. & n.a. & 0,068 & 0,07 & n.a. & n.a. & n.a. \\
\hline Ho & n.a. & n.a. & n.a. & n.a. & n.a. & n.a. & n.a. & n.a. & 0,013 & 0,014 & n.a. & n.a. & n.a. \\
\hline Er & n.a. & n.a. & n.a. & n.a. & n.a. & n.a. & n.a. & n.a. & 0,037 & 0,038 & n.a. & n.a. & n.a. \\
\hline $\mathrm{Tm}$ & n.a. & n.a. & n.a. & n.a. & n.a. & n.a. & n.a. & n.a. & 0 & 0 & n.a. & n.a. & n.a. \\
\hline $\mathrm{Yb}$ & n.a. & n.a. & n.a. & n.a. & n.a. & n.a. & n.a. & n.a. & 0,048 & 0,05 & n.a. & n.a. & n.a. \\
\hline $\mathrm{Lu}$ & n.a. & n.a. & n.a. & n.a. & n.a. & n.a. & n.a. & n.a. & 0,01 & 0,007 & n.a. & n.a. & n.a. \\
\hline
\end{tabular}

Metas. = serpentinito metassomatizado; Serp. = serpentinito; Esp serp. = espinélio serpentinito

outra metassedimentar. A primeira consiste de rochas vulcânicas félsicas de afinidade cálcio-alcalina e rochas vulcânicas intermediárias a máficas de caráter transicional a toleiítico. $\mathrm{O}$ vulcanismo foi em parte sub-aquoso e explosivo e associado à subducção de crosta oceânica sob um continente, possivelmente durante o Neoproterozóico (Marques et al. 1998a). A seqüência metassedimentar consiste de espessa sucessão de metapelitos e metassemipelitos, com intercalações de quartzito, lentes de mármore e raros metaconglomerados oligomíticos. A sedimentação ocorreu sob condições de mar raso, o que é compatível com o caráter sub-aquoso das rochas vulcânicas associadas (Marques et al. 1998b).

As lentes de rochas metaultramáficas se associam preferencialmente com rochas metavulcânicas máficas a intermediárias, mais raramente metassedimentares, e seus contatos com as encaixantes são exclusivamente tectônicos. A avançada serpentinização das lentes dificulta o estudo de suas características geoquímicas pri- márias. Contudo, dados petrográficos mostram que parte destas rochas derivam de protólitos cumuláticos de olivina e olivina + ortopiroxênio. Por outro lado, o padrão geoquímico dos serpentinitos é compatível com o de rochas mantélicas, embora o comportamento dos ETR seja, a primeira vista, distinto do esperado para um manto primitivo. No entanto, o baixo conteúdo de ETR e o seu padrão convexo quando normalizado ao manto primitivo são característicos de harzburgitos e dunitos de seção basal de ofiolitos (Frey 1984, Melcher et al. 1999).

Dados geofísicos (Costa et al. 1995) mostram que a região da Suíte Metamórfica Porongos representa uma área de colagem tectônica, o que invoca ambiente de subdução e corrobora a possibilidade de ocorrência de mèlanges com ofiolitos. Este contexto é consistente com o ambiente sugerido pelas rochas metavulcânicas e explica tanto os contatos exclusivamente tectônicos das lentes metaultramáficas, quanto a ocorrência íntima destas com rodingitos e rochas metabásicas metassomatizadas e de porções 

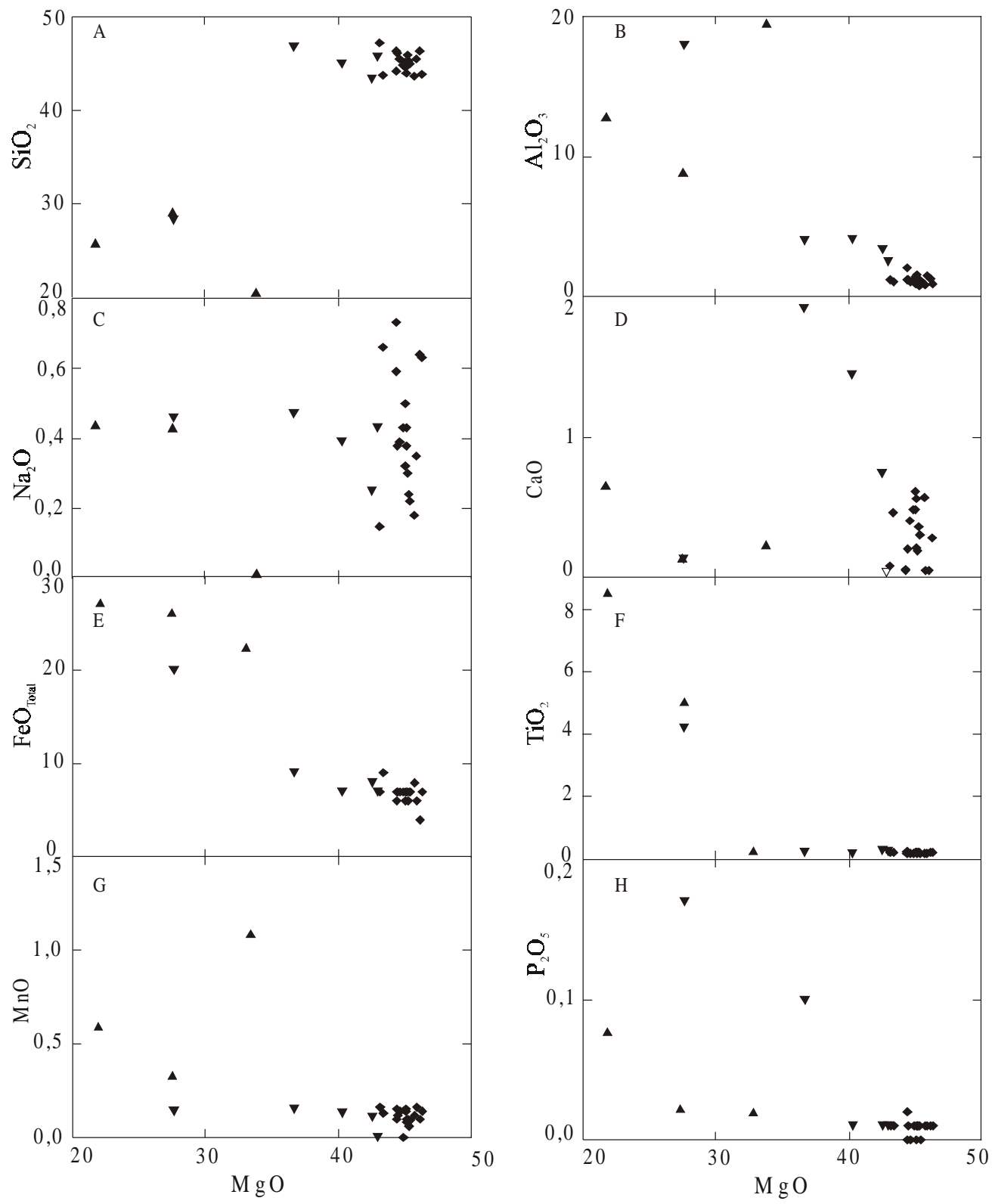

Serpentinito

Serpentinito metassom atizado

Serpentinito com espinélios

Figura 6 - Diagramas de variação química dos serpentinitos da Antiforme Capané.

cumuláticas com porções mantélicas. Deste modo, interpretamos as rochas metaultramáficas da Antiforme Capané como uma porção desmembrada da base de um ofiolito, agregada à Suíte Metamórfica Porongos durante o Ciclo Brasiliano.

Agradecimentos Ao Conselho Nacional de Desenvolvimento Científico e Tecnológico pela Bolsa de Mestrado concedida à J.C.
Marques e pela(s) Bolsas de Produtividade concedidas a A. Roisenberg e H. Jost. Ao Curso de Pós-Graduação em Geociências e ao Instituto de Geociências da Universidade Federal do Rio Grande do Sul pelos recursos para trabalhos de campo e laboratório e ao Instituto de Geociências da Universidade de Brasília pelo acesso ao Laboratório de Geoquímica e ao de Difratometria de Raios$\mathrm{X}$. Aos revisores da RBG pelas sugestões ao manuscrito.

\section{Referências}

Bitencourt M. F. 1983. Metamorfitos da região de Caçapava do Sul, RS

Geologia e relações com o corpo granítico. In: SBG, Simp. Sul-bras.

Geol., 1, Porto Alegre, Atas, 37-48.
Boaventura G.R. 1991. Performance do espectrômetro de emissão com plasma (ICP), spectroflame FVMO3, para determinação de 20 elementos químicos nas amostras de referência geoquímica DNC-1, W- 

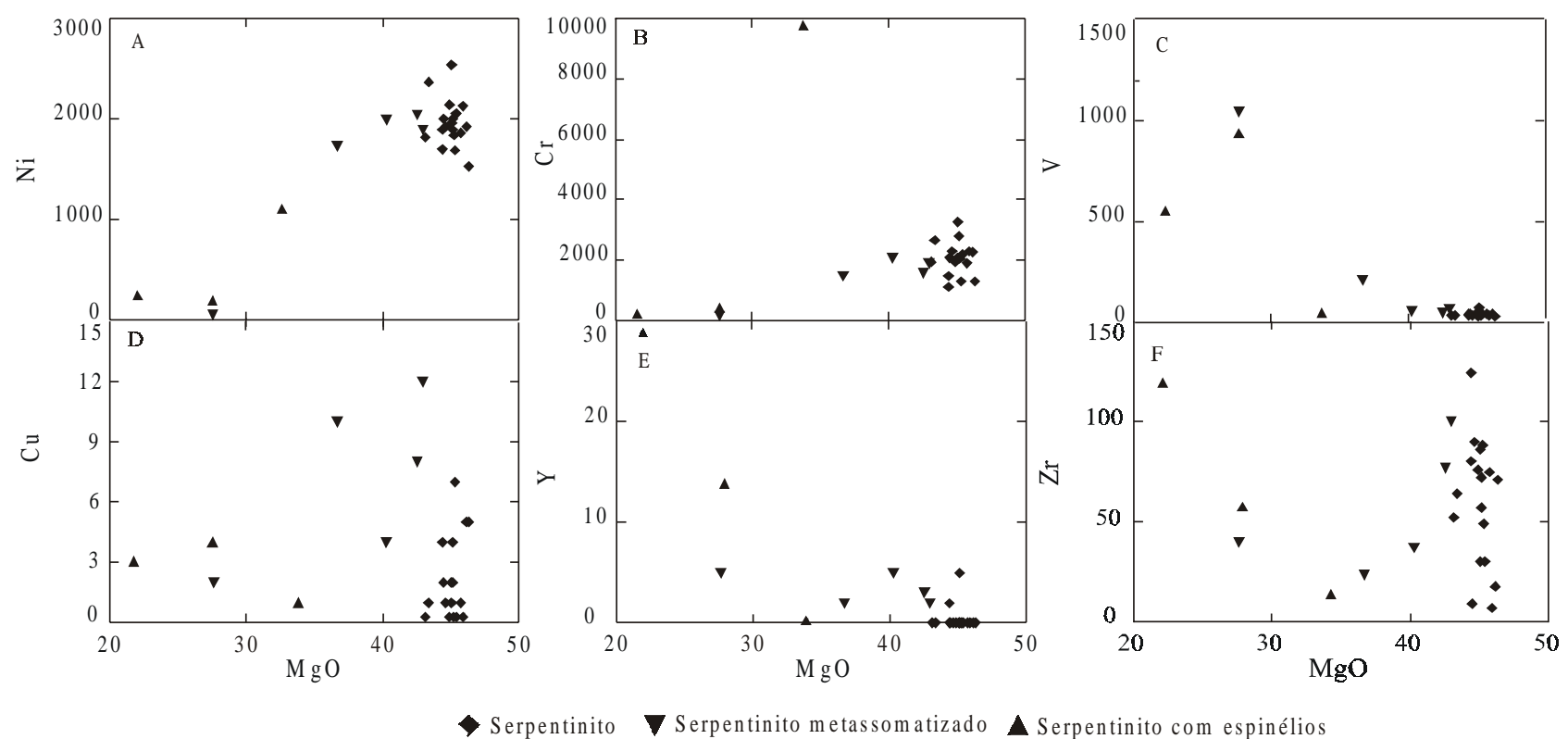

Figura 7 - Diagramas de variação química dos serpentinitos da Antiforme Capané.

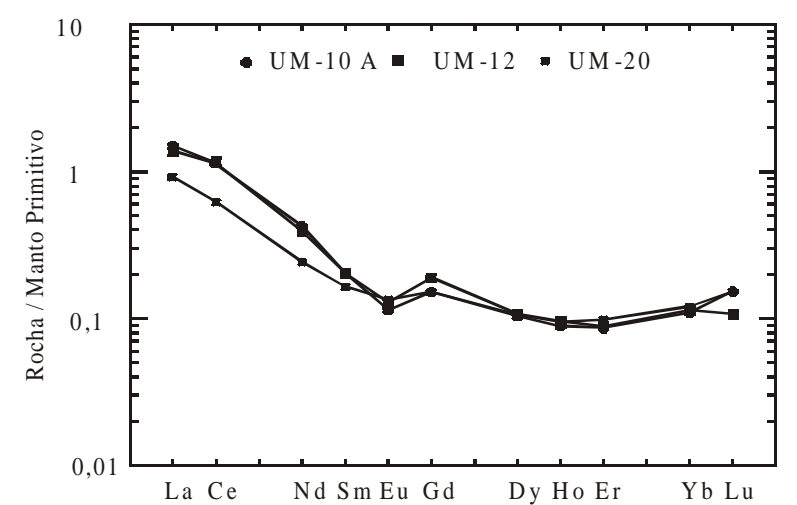

Figura 8 - Padrões de ETR dos serpentinitos da Antiforme Capané normalizados ao manto primitivo (valores de McDonough \& Sun 1995).

2, UNB B-1 e UNB G-1. In: SBGq., Cong. Bras. Geoq., 1, São Paulo, Anais, 1:423-426.

Bucher K. \& Frey M. 1994. Petrogenesis of Metamorphic Rocks, Complete Revision of Winkler's Textbook. 6 ed. Berlin-Germany, Springer-Verlag. 318p.

Camozzato E., Sander A., Ramgrab G.E., Wildner W. 1994. Milonitos alcalinos-peralcalinos da região de Candiota, RS. In: Cong. Bras. Geol., 38, Balneário Camboriú, Boletim de Resumos Expandidos, 3:89-90.

Chemale Jr. F. 1982. Geologia da região de Palma, São Gabriel, Rio Grande do Sul. Inst. de Geociências, Universidade Federal do Rio Grande do Sul, Porto Alegre, Dissertação de Mestrado, 136 p.

Chemale Jr. F. 2000. Evolução geológica do Escudo Sul-riograndense. In M. Holz e L.F. De Ros (eds) Geologia do Rio Grande do Sul. Porto Alegre, CIGO/UFRGS, 13-52.

Coleman R.G. 1977. Ophiolites: Ancient Oceanic Lithosphere? Berlin, Sprienger-Verlag, 229p.

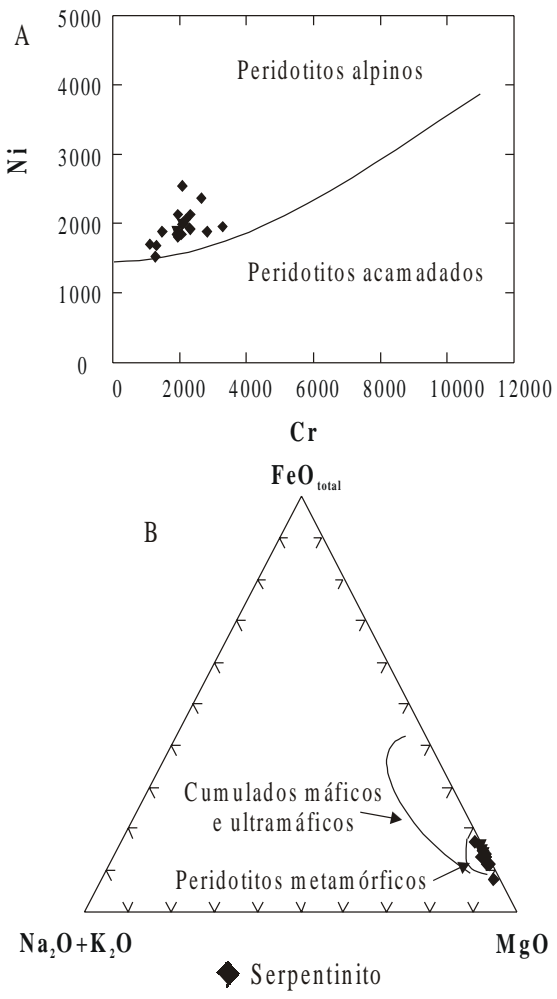

Figura 9 - Comportamento geoquímico dos serpentinitos da Antiforme Capané. (A) Diagrama $\mathrm{Cr}$ x Ni com campos discriminantes de Malpas \& Stevens (1977). (B) Diagrama AFM com campos discriminantes de Coleman (1977).

Costa A.F.U., Ramgrab G.E., Fernandes L.A.D., Camozzato E., Azevedo M.L.V. 1995. Compartimentação tectônica das associações de rochas pré-cambrianas do Escudo Sul-rio-grandense baseada em dados de magnetometria e gravimetria. In: SBG, Simp. Nac. Est. 
Tectônicos, 5, Gramado, Boletim de Resumos Expandidos, 1:236238.

Frey F.A. 1984. Rare earth elements in upper mantle rocks. In: P. Henderson (ed) Rare Earth Element Geochemistry. Amsterdam, Elsevier,153-203.

Garcia M.A.M. 1980. Petrologia do Complexo Palma, Rio Grande do Sul. Inst. de Geociências, Universidade Federal do Rio Grande do Sul, Porto Alegre, Dissertação de Mestrado,133 p.

Hartmann L.A. \& Jost H. 1980. Gnaisses alcalinos da Antiforme Capané Acta Geol. Leopolden., 4:13-25.

Hartmann L.A. \& Remus M.V.D. 2000. Origem e evolução das rochas ultramáficas do Rio Grande do Sul desde o Arqueano até o Cambriano. In: M. Holz \& L.F. De Ros (eds) Geologia do Rio Grande do Sul. Porto Alegre, CIGO/UFRGS, 53-78.

Jost H. \& Bitencourt M.F. 1980. Estratigrafia e tectônica de uma fração da faixa de dobramentos de Tijucas no Rio Grande do Sul. Acta Geol. Leopolden., 7:27-60.

Jost H. \& Hartmann L.A. 1979. Rodingitos do Rio Grande do sul, Brasil. Acta Geol. Leopolden., 3:77-91.

Jost H. \& Hartmann L.A. 1984. Província Mantiqueira setor meridional, In F.F.M. Almeida \& Y. Hasui (eds.) O Pré-Cambriano do Brasil. São Paulo, Blüncher, 345-367.

Jost H. 1981. Geology and metallogeny of the Santana da Boa Vista region southern Brasil. University of Georgia, Athens, $\mathrm{PhD}$ Thesis, $208 \mathrm{p}$.

Malpas J. \& Stevens R.K. 1977. The origin and emplacement of the ophiolite suite with examples from Western Newfoundland. Geotectonics, 11:453-466.

Marques J.C., Jost H., Roisenberg A., Frantz J.C. 1998a. Eventos ígneos da Suíte Metamórfica Porongos na área da antiforme Capané, Cachoeira do Sul - RS. Rev. Bras. Geoc., 28:419-430.

Marques J.C., Jost H., Roisenberg A., Frantz J.C. 1998b. Rochas metassedimentares, geologia estrutural e metamorfismo da Suíte Metamórfica Porongos na área da Antiforme Capané, Cachoeira do Sul - RS. Rev. Bras. Geoc., 28:467-472.

McDonough W.F. \& Frey F.A. 1989. Rare earth elements in upper mantle rocks. In: B.R. Lipin \& G.A. McKay (eds.), Mineralogical Society of America, Reviews Mineral., 21:99-145.

McDounough W.F. \& Sun S. -S. 1995. Composition of the Earth. Chem. Geol., 120:223-253.

Melcher F., Grum W., Thalhammer T.V., Thalhammer O.A.R. 1999. The giant chromite deposits at Kempirsai, Urals: constraints from trace element (PGE, REE) and isotope data. Mineral. Depos., 34:250272.

Naumann M.P. 1985. O Complexo Vulcano-sedimentar-ultramáfico e granitóides da região de Ibaré, $R S$. Inst. de Geociências, Universidade Federal do Rio Grande do Sul, Porto Alegre, Dissertação de Mestrado, $161 \mathrm{p}$

Porcher C.C. \& Fernandes L.A.D. 1990. Relações embasamento/ "cobertura" na porção ocidental do Cinturão Dom Feliciano: um esboço estrutural. Pesquisas, 17:72-96.

Porcher C.C. 1992. Caracterização das Condições de Fluxo em uma Zona de Cisalhamento Tangencial na Região de Santana da Boa Vista. Inst. de Geociências, Universidade Federal do Rio Grande do Sul, Porto Alegre, Dissertação de Mestrado, 192 p.
Rego I.T.S.F. 1980. Complexo Básico-Ultrabásico de Pedras Pretas, RS Aspectos petrológicos e geoquímicos. Inst. de Geociências, Universidade Federal do Rio Grande do Sul, Porto Alegre, Dissertação de Mestrado, 98 p.

Remus M.V.D. 1990. Geologia e Geoquímica do Complexo Cambaizinho, São Gabriel, RS. Inst. de Geociências, Universidade Federal do Rio Grande do Sul, Porto Alegre, Dissertação de Mestrado, 267 p.

Remus M.V.D., Faccini U.P., Tedesco M.A., Philipp R.P. 1987. Evolução estrutural dos metamorfitos da unidade Porongos a sul do Rio Camaquã. In: SBG, Simp. Sul-bras. Geol., 3, Curitiba, Atas, 1:223-243.

Ribeiro M., Bochi P.R., Figueiredo Filho P.M., Tessari R. 1966 Geologia da quadrícula de Caçapava do Sul. Rio Grande do Sul. Rio de Janeiro, DNPM/DFPM. p. 1-232. (Boletim 127).

Roden M.F., Frey F.A., Francis D.M. 1984. An example of consequent mantle metasomatism in peridotite inclusions from Nunivak Island, Alaska. J. Petrol., 25:546-577.

Santos E.L., Azevedo G.C., Maciel L.A.C., Mossmann R., Remus M.V.D. 1990. Mapeamento geológico de sequências metavulcanosedimentares do oeste do escudo Sul-rio-grandense, RS. In: SBG, Cong. Bras. Geol., 36, Natal, Anais, 6:2976-2990.

Santos E.L., Ramgrab G.E., Maciel L.A., Mosmann R. 1989. Mapa Geológico do estado do Rio Grande do Sul e parte do escudo Sul-riograndense. DNPM- $1^{\circ}$ Distrito Regional.

Soliani Jr. E. 1986. Os Dados Geocronológicos do Escudo Sul-riograndense e suas Implicações de Ordem Geotectônica. Inst. de Geociências, Universidade de São Paulo, São Paulo, Tese de Doutorado, $239 \mathrm{p}$.

Teixeira W. 1982. Folhas SH. 22 - Porto Alegre, SI. 22 - Lagoa Mirim e SH. 21 Uruguaiana. Interpretação dos dados radiométricos e evolução geocronológica. In: Projeto RADAMBRASIL, Florianópolis (relatório inédito)

Villwock J.A. \& Loss 1973. Um novo tipo de complexo básico-ultrabásico na faixa serpentinítica do Pré-cambriano do Rio Grande do Sul. Notas e Estudos da Escola de Geologia UFRGS, 2:15-22.

Wicks F.J. \& Whittaker E.J.W. 1977. Serpentine textures and serpentinization: Canadian Mineralogist, 15: 459-488.

Wildner W. 1990. Caracterização Geológica e Geoquímica das Sequências Ultramáfica e Vulcano-sedimentares da Região de Bossoroca$R S$. Inst. de Geociências, Universidade Federal do Rio Grande do Sul, Porto Alegre, Dissertação de Mestrado, 170 p.

Wildner W., Camozzato E., Orlandi Filho V., Basei M.A.S. 1996. Rochas vulcanogênicas do Cinturão Metamórfico Porongos na Antiforme do Godinho, região do Passo da Cuia-RS. In: SBG, Cong. Bras. Geol., 39, Salvador, Anais, 2:146-148.

Wilson, A.D. 1955. Determination of ferrous iron in rocks and minerals. Bull. Geol. Surv. G. B., 9:56-58.

Zarpelon P.R. 1986. Geologia Estrutural, Estratigrafia e Petrologia de uma parte do "greenstone belt" Cerrito do Ouro, Município de São Sepé, RS. Inst. de Geociências, Universidade Federal do Rio Grande do Sul, Porto Alegre, Dissertação de Mestrado, 215 p.

Manuscrito A-1382

Recebido em 10 de outubro de 2002 Revisão dos autores em 25 de março de 2003 Revisão aceita em 29 de março de 2003 